УДК 347.4

DOI 10.37566/2707-6849-2020-3(32)-7

доцент каредри приватного права Чернівецького національного університету імені Юрія Федьковича, кандидат юридичних наук

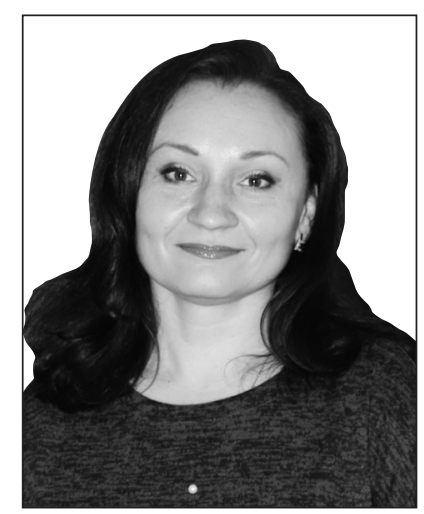

\title{
ПРАВО ДОВІРЧОЇ
}

\section{ВЛАСНОСТІ: ІНТЕГРАЦІЯ} ЗОБОВ'ЯЗАЛЬНИХ ТА

\section{ПРОПРІЕТАРНИХ ЕЛЕМЕНТІВ}

Інститут довірчої власності, що має багатовікову історію розвитку в зарубіжних країнах, для національної правової системи досі перебуває на етапі первісного становлення, що зумовлено цілою низкою суперечностей і труднощів, пов'язаних як з науково-теоретичним обгрунтуванням, так і 3 можливістю реалізації цих положень на практиці. На наше глибоке переконання, розвиткові інституту довірчої власності перешкоджає відсутність міцного теоретичного обгрунтування, пов'язаного з розумінням сутності досліджуваних відносин. Проблемні питання зумовлені також відсутністю усталеної судової практики у спорах, що випливають із поки що незначного відсотка практичного використання аналізованих положень.

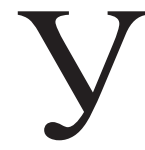

зв'язку з удосконаленням законодавчого регулювання довірчих відносин у багатьох державах світу та фактичним усуненням дуалізму в країнах загального права в наш час відбувається відчутне зближення інститутів трасту та довірчої власності (довірчого управління), в результаті чого до речово-правової за своєю природою конструкції трасту дедалі очевидніше додаються зобов'язально-правові елементи. Все це накладає відчутний відбиток і на практику запозичення цих інститутів до континентальної системи права, в якій останнім часом окреслені інститути набувають дедалі більшого поширення у різних формах.

Ми впевнені, що дослідження права довірчої власності наразі слід розглядати як новий магістральний напрям у науці цивільного права. Водночас відсутність грунтовних 
наукових досліджень питань емпіричного усвідомлення та практичного застосування права довірчої власності не дає змоги в цій статті охопити всі без винятку проблемні аспекти правореалізації цього інституту. У зв'язку з цим ми навмисно звузили об'єкт дослідження виключно до аналізу різних теоретичних підходів до розуміння сутності права довірчої власності на сучасному етапі, які, на нашу думку, є визначальними для формування вектору подальших дослідницьких пошуків у цій царині.

Найбільш масштабна інтервенція норм про довірчу власність у вітчизняне правове поле відбулася у вересні 2019 року, коли Законом України «Про внесення змін до деяких законодавчих актів України щодо стимулювання інвестиційної діяльності в Україні» № 132-IX [1] було внесено зміни та доповнено Земельний кодекс України, Цивільний кодекс України, Кодекс України з процедур банкрутства, закони України «Про нотаріат», «Про банки і банківську діяльність», «Про забезпечення вимог кредиторів та реєстрацію обтяжень», «Про оцінку земель», «Про систему гарантування вкладів фізичних осіб», «Про державну реєстрацію речових прав на нерухоме майно та їх обтяжень», «Про виконавче провадження» та ін.

На жаль, питання довірчої власності, незважаючи на законодавчі спроби унормувати цей інститут, не можна визначити таким, що досконало врегульований в Україні. Останнім часом законодавець всіляко намагається адаптувати традиційні положення класичної системи загального права («trust», «strict settlement», «use upon a use», «seisin», «equitable lien» та ін.) до вітчизняних реалій, що об'єктивно зумовлює численні приклади непослідовності та неузгодженості деяких правових положень, про які ми вже писали раніше [2, с. 22-24]. Так, право довірчої власності законодавець визначає за допомогою таких взаємовиключних юридичних категорій, як:

- особливий самостійний вид права власності (ч. 2 ст. 316 ЦКУ),

- похідний від договору управління майном інститут (ч. 2 ст. 1029 ЦКУ),

- спосіб виконання зобов'язання (ч. 1 ст. 546 ЦКУ).

Інакше регламентує це питання ст. 4 Закону України «Про державну реєстрацію речових прав на нерухоме майно та їх обмежень» [3], яка закріплює дуалістичний підхід до розуміння права довірчої власності, оскільки зазначає, що державній реєстрації підлягають окремо:

1) право довірчої власності як спосіб забезпечення виконання зобов'язання (п. 1) ч. 1);

2) право довірчої власності як речове право, похідне від права власності (абз. 9, п. 2) ч. 1).

Нагальна необхідність докладного дослідження права довірчої власності зумовлена також недосконалістю та неузгодженістю правових норм, що призводить до можливості їх довільного тлумачення правозастосовцями, додає зайвої варіативності у виокремленні правової природи цього інституту, унеможливлює уніфікацію юридичної термінології та вичерпних характеристик окресленого правового феномену. Законодавець та учасники цивільно-правових відносин доволі часто використовують непослідовно наведені категорії, не розмежовуючи їхнього змісту або безпідставно ототожнюючи. 
Як бачимо, у наш час відсутнє єдине доктринальне розуміння природи довірчої власності. I це далеко не повний перелік неузгоджених термінологічних зворотів, що найбільше впливають на практику застосування досліджуваного предмета, не беручи до уваги теоретичні диспути щодо доречності використання понять форми/види/типи власності, що були досить детально досліджені та розмежовані I. Спасибо-Фатєєвою ще у 2009 році, яка наголосила, що таких випадків, коли термінологічно об'єднуються різні правові явища, чимало (публічна власність, корпоративна власність, інтелектуальна власність) [4, с. 152].

Опосередкованим підтвердженням цього $€$ практична сторона застосування права довірчої власності. Аналіз судової практики також засвідчує той факт, що наразі досліджувані нами відносини перебувають на етапі свого становлення, оскільки ще декілька років тому (до набрання чинності Законом України «Про внесення змін до деяких законодавчих актів України щодо стимулювання інвестиційної діяльності в Україні» № 132-IX від 20.09.2019 р. [1]) суди нашої держави були переповнені справами щодо спорів власників із суб'єктами надання фінансових послуг, які водночас були довірчими власниками отриманих в управління активів згідно 3 раніше діючим законодавством [до прикладу, 5; 6 та ін.].

Натомість останнім часом кількість справ щодо правовідносин довірчої власності, за чинним нині цивільним законодавством, практично нульова. Спори, у яких наразі фігурують довірчі правовідносини, пов'язані переважно з виконанням довірчих операцій [наприклад, 7; 8 та ін.] або стосуються реалізації приписів Закону України «Про електронні довірчі послуги» від 5 жовтня 2017 року № 2155-VIII [9], насамперед щодо використання електронного цифрового підпису, що в жодному випадку не стосується сутності права довірчої власності в розумінні ст. $597^{1}$ Цивільного кодексу України (далі - ЦК України). Згаданий нормативно-правовий акт теж не позбавлений певних законодавчих суперечностей, на що неодноразово звертали увагу науковці [10, с. 104-105].

Теоретичні дослідження і напрацювання вітчизняних вчених у цьому контексті зосереджені здебільшого на понятті «trust», що трансформує дискусію доцільності запровадження права довірчої власності у розгляд полемічного питання «розділеної» власності, пропрієтарності тощо. На думку Р. Майданика, правова природа довірчого правовідношення полягає у визнанні правового титулу фідуціарія специфічною формою майнового привласнення, що сформоване на стику права власності та права володіння [11, с. 7].

Інакше кажучи, пропрієтарність як ознака певного правового явища, що насамперед засвідчує його належність до так званої речової сфери, як первісного прояву його сутності, і вже потім - залежно від специфіки конкретних правовідносин може екстраполювати на себе вплив і зобов'язально-правової сфери. Таку аналогію простежував свого часу ще О. Іоффе, який спостерігав, як сформовані під впливом пропрієтарної концепції комплексні правові інститути (насамперед це стосувалося інтелектуальної власності) з часом зазнавали дедалі більш трансформуючих видозмін переважно зобов'язально-правових конструкцій. За словами вченого, 
дещо подібне відбулося з винахідницьким правом, яке спершу кваліфікувалося як суто промислова власність, а потім - як особливе право, що виникає за авторської системи (в особі автора), але здійснюється на підставі договорів після відповідного звернення (в особі заявника, котрий сам якщо і не $\epsilon$ автором, то діє за договором 3 останнім) [12, с. 156].

Загалом же, у пострадянській юридичній спільноті поширеною є практика вивчення окремих проявів довірчої власності з пропрієтарної (англ. proprietary власність, привласнення) точки зору. Серед перших грунтовне дослідження цього питання було проведено Р. Шишкою, який переконливо довів, що з позиції сьогодення $€$ нагальна потреба пошуку іншої теорії, яка б точніше відображала змістовну сторону цих відносин [13, с. 315].

Сформований вченим ще на початку століття висновок знаходить своє підтвердження й у контексті нещодавніх законодавчих новел, насамперед тих, що стосуються кардинально оновлених довірчих правовідносин, де до класичного пропрієтарного інституту «власності» додаються вочевидь зобов'язально-правові складові, що в результаті призводить до виникнення нетипової для українського права конструкції «право довірчої власності», котра зрештою в різних формах поширена в законодавстві іноземних держав. Це пояснює той факт, що при застосуванні традиційних науково-пізнавальних підходів до розуміння права довірчої власності виникають численні парадокси й непорозуміння, пов'язані в першу чергу з загальним уявленням про ці об’єкти як про виключно пропрієтарні за своєю природою.

Всебічний аналіз вищезазначених питань у працях українських дослідників цивільного права та загальної теорії права демонструє складність досліджуваного питання, а також труднощі імплементації іноземного правового інституту в національне цивільне законодавство. Як влучно зауважила І. Спасибо-Фатєєва, довірча власність не являє собою те право власності, яке має речову природу і не може існувати в режимі довірчої власності, відомої англійському праву [4, с. 152].

Наразі всі існуючі науково-теоретичні підходи вчених-цивілістів до визначення природи довірчих правовідносин можна умовно позиціонувати за трьома основними підходами, а саме:

1. Облігаторний nidxid (від лат. «obligatoria»- зобов'язання, забезпечення), прибічники якого [14; 15 та ін.] відстоюють точку зору, згідно з якою для довірчих правовідносин як зобов'язальних характерним є задоволення інтересів уповноваженої особи шляхом вчинення певних обов'язкових дій зобов'язаною особою щодо належних довірителеві певних майнових благ. У силу таких міркувань довірчий власник як кредитор отримує відповідне майно від довірчого засновника 3 конкретною метою забезпечити виконання зобов'язання довірчого власника як боржника. Тобто сутністю та призначенням таких дій $\epsilon$ не сам факт передання певного майна від боржника до кредитора (на відміну від речових правовідносин, де передавання майна є свого роду самоціллю), а забезпечити цим самим виконання зобов'язання за кредитним договором чи договором позики. Таким чином, довірчі правовідносини в цьому випадку будуть характеризуватися насамперед своєю зобов' язальною природою, що на етапі 
правореалізації охоплюватиме цілу низку зобов'язань (наприклад, зобов'язання не відчужувати таке майно, окрім випадків звернення стягнення на нього чи викупу його для суспільних потреб у встановленому законом порядку).

В якості законодавчого підтвердження своїх висновків прихильники зобов'язально-правового підходу розуміння сутності довірчих правовідносин використовують частину першу ст. 546 ЦК України, де закріплено, що правом довірчої власності забезпечується виконання зобов'язання. Тим більше, що основним обгрунтуванням послідовників цього підходу є той факт, що сам параграф про довірчу власність текстуально закріплений у главі 49 ЦК України «Забезпечення виконання зобов'язань».

Водночас переважна більшість прибічників такого підходу відзначають, що для наступного використання довірчої власності як способу забезпечення виконання зобов' язань потрібно, для початку, чітко визначити сутність цього правового явища та вдосконалити його правове регулювання [15, с. 81$]$.

2. Респосесійний підхід (від лат. «res»-piч, «possessio»-володіння), прибічники якого наголошують на виключно речовій природі довірчих правовідносин [зокрема 4; 11 та ін.], оскільки, на їхню думку, повноваження довірчого власника, якому протистоїть невизначене коло осіб, сконструйовані за схемою, що аналогічна повноваженням власника і тому не можуть бути нічим іншим, як обмеженими речовими правами. Як зазначає $Є$. Суханов, «передавання власником частини чи навіть усіх своїх повноважень довірчому власнику сама по собі не призводить до втрати ним права власності» [16, с. 243], оскільки виступає в якості однієї з форм здійснення повноважень власника і паралельно є видом забезпечення виконання зобов'язань.

Інакше кажучи, поціновувачі такого розуміння довірчих правовідносин визначають первинність речового характеру цих правовідносин і обгрунтовують свої твердження посиланням на зміст окремих норм ЦК України, а саме:

- частини другої ст. 316, де визначено, що право довірчої власності є особливим видом права власності, що виникає внаслідок закону або договору;

- частини другої ст. $597^{1}$ (кредитор стає довірчим власником у силу отримання майна саме в довірчу власність) тощо.

3. Комбінаторний nidxid (від лат. «соmbinant»- поєднувати, комбінувати), прибічники якого [2; 17 та ін.] наголошують на тому, що довірчі правовідносини перебувають наразі на стику зобов'язальних і речових відносин, i тому всі аргументи поціновувачів попередніх течій тут пропонують використовувати не в якості взаємовиключних чи взаємозаперечних, а, навпаки, взаємодоповнюючих критеріїв. Так, за словами Л. Міхєєвої, континентальна правова догма здійснює виключний поділ усіх майнових прав на речові і зобов'язальні (де речові права призначені для закріплення майна за носієм права, а зобов'язальні - для його обігу), і тому неправильно намагатися протиставити речові правовідносини зобов'язальним, які в сукупності виступають двома частинами одного цілого [18, с. 134-135].

Ці міркування розвиває А. Гончарук, яка визначає, що за своєю юридичною природою довірча власність $є$ речовим правом, яке належить довірчому власнику, і обтяжене зобов'язанням діяти в чужому інтересі [17, с. 98]. 
Дотримується останнього комбінаторного підходу і вітчизняний законодавець, який у частині другій ст. $597^{1}$ ЦК України закріплює одночасно зобов'язальний i речовий характер довірчих правовідносин у нашій державі. Це очевидно простежується за аналогією з правом довірчої власності, що детермінує виникнення, зміну чи припинення довірчих правовідносин. I оскільки для права довірчої власності нормотворець вживає паралельно зобов'язально-характеризуючі («право довірчої власності є способом забезпечення виконання зобов'язань») та речово-характеризуючі («право довірчої власності є різновидом права власності на майно») компоненти, то це саме можна презюмувати і для довірчих правовідносин.

Принагідно зауважимо, що наші умовиводи в жодному разі не призводять до ототожнення взаємопов' язаних, але різних за своєю сутністю понять «право довірчої власності» $\mathrm{i}$ «довірчі правовідносини». Радше вони характеризуються однаковими ознаками, які за наявності в одного з названих вище понять 3 достеменною вірогідністю будуть властиві й другому з них.

Так само вирішується й питання захисту порушених, невизнаних чи оспорюваних довірчих правовідносин. 3 одного боку, законодавець фіксує абсолютний характер ix охорони, що притаманне речовим правовідносинам (наприклад, відповідно до частини першої ст. $597^{8}$ ЦК України звернення стягнення на об 'єкт довірчої власності відбувається шляхом його продажу будь-якій особі-покупиеві), а з другого декларує також можливість застосування відносних засобів захисту, що вочевидь властиво для зобов'язальних правовідносин (зокрема, у частині третій сm. $597^{2}$ ЦК Украӥни встановлено, щзо режим довірчої власності не поширюється на плоди, продукцію та доходи, одержані від використання об 'єкта довірчої власності).

Висновки. Вважаємо за доцільне підсумувати, що комплексна правова категорія «довірча власність» належить до тих явищ цивільного права, законодавче регулювання яких тільки починає набирати упорядкованого характеру, що пояснює численні приклади нормативної непослідовності та неузгодженості положень правових актів. 3 іншого боку, це дає підстави прогнозувати значний науково-теоретичний і практичний інтерес до подальшого дослідження окреслених питань 3 метою оптимізації правозастосування та правореалізації.

Запровадження нового комплексного інституту довірчої власності безальтернативно вимагає негайної редакційної трансформації нормативно-правових актів, що невиправдано без вдумливого запозичення іноземного досвіду правового регулювання досліджуваних відносин, у тому числі в його історичній ретроспективі, ретельного аналізу всіх помилок та «неробочих» норм, які були допущені минулими роками в праві зарубіжних країн.

Основними шляхами для розв'язання окресленої проблематики $є$ насамперед якнайшвидша уніфікація положень нормативно-правових актів, що безпосередньо чи опосередковано регламентують питання виникнення, зміни чи припинення довірчих правовідносин. 


\section{Перелік використаних джерел}

1. Про внесення змін до деяких законодавчих актів України щодо стимулювання інвестииійної діяльності в Україні: Закон України від 20.09.2019 p. № 132-IX. URL: https:// zakon.rada.gov.ua/laws/show/132-20\#n201 Дата звернення 03.08.2020 p.

2. Кіріяк О. В. Актуальні проблеми правового регулювання довірчої власності. Міжнародна науково-практична конференція «Актуальні питання сучасного державотворення: проблеми та перспективи», присвячена 100-річчю від дня народження та річниці з дня смерті О. В. Коваля (Черкаси, 1 листопада 2019 р.). Черкаси, 2019. С. 22-24.

3. Про державну реєстрачію речових прав на нерухоме майно та їх обмежень: Закон Украӥни від 01.07.2004 p. № 1952-IV. URL: https://zakon4.rada.gov.ua/laws/show/1952-15

4. Спасибо-Фатєєва I. В. Форми права власності. Вісник Академї правових наук України. 2009. № 3. С. 145-154.

5. Ухвала Бердянського міськрайонного суду Запорізької області у справі № 2-1622/11 від 03.11.2014 р. Сдиний державний реєстр судових рімень. URL: http://www.reyestr.court. gov.ua/Review/49239108

6. Ухвала Придніпровського районного суду м. Черкаси у справі № 711/3164/15-u (провадження № 6/711/133/15) від 20.05.2015 р. Єдиний державний реєстр судових рішень. URL: http://www.reyestr.court.gov.ua/Review/48235868

7. Заочне рішення Мукачівського міськрайонного суду Закарпатської області у справі № 303/5985/19 (провадження № 2/303/137/20) від 19.03.2020 p. Сдиний державний реєстр cyдових рішень. URL: http://www.reyestr.court.gov.ua/Review/88310995

8. Ухвала Дзержинського районного суду м. Харкова у справі 638/15749/18 (провадження № 23/638/142/19) від 14.01.2019 р. Сдиний державний реєстр судових рішень. URL: http://www.reyestr.court.gov.ua/Review/49239108

9. Про електронні довірчі послуги: Закон Украӥни від 05.10.2017 p. № 2155-VIII. URL: https://zakon.rada.gov.ua/laws/show/2155-19/ed20200213\#Text

10. Білочерковець Н. В. Технологічна нейтральність та заборона дискримінації як ключові принципи державного регулювання електронних довірчих послуг: поняття та ознаки. Підприємництво, господарство і право. 2018. № 1. С. 103-109.

11. Майданик Р. А. Проблеми регулювання довірчих відносин у изивільному праві України: автореф. дис. ... докт. юрид. наук: 12.00.03. Київ, 2003. 31 с.

12. Иофре О. С. Цивилистическая доктрина империализма. Избранные труды по гражданскому праву: Из истории ичивилистической мысли. Гражданское правоотношение. Критика теории «хозяйственного права». Москва, 2000. 448 с.

13. Шиика Р. Б. Пропрієтарна теорія інтелектуальної власності. Вісник Харківського національного університету внутрішніх справ. 2001. Вип. 16. С. 311-315.

14. Рябчинська А. О. Право довірчої забезпечувальної власності в зарубіжних краӥнах: досвід Франиії та Румунії. Вчені записки ТНУ ім. В. І. Вернадського. Серія Юридичні науки. 2019. T. 30 (69). № 3. C. 51-57.

15. Некіт К. Г. Довірча власність як спосіб забезпечення виконання зобов'язань: аналіз вітчизняного та зарубіжного законодавства. Часопис циивілістики. Вип. 21. 2016. С. 78-81. 
16. Комментарий части второй Гражданского кодекса Российской Федерации для предпринимателей: подгот. М. И. Брагинский и др. Москва: Правовая культура, 1996. 546 с.

17. Гончарук А. А. Право довірчої власності. Бюлетень Міністерства юстииії України. 2014. № 2. C. 97-101.

18. Михеева Л. Ю. Доверительное управление имуществом. Комментарий законодательства: монография. Москва: Юрист, 2009. 238 с.

\section{References}

1. On Amendments to Certain Legislative Acts of Ukraine Concerning the Stimulation of Investment Activity in Ukraine: Law of Ukraine of September 20, 2019 № 132-IX. URL: [Electronic resource] - Access mode: https://zakon.rada.gov.ua/laws/show/132-20\#n201. [ukr.]

2. Kiriyak O. V. Actual problems of legal regulation of trust property. I O. V. Kiriyak/International scientific-practical conference "Current issues of modern statehood: problems and prospects", dedicated to the 100th anniversary of the birth and anniversary of the death of OV Koval (Cherkasy, November 1, 2019). Cherkasy, 2019. pp. 22--24. [ukr.]

3. On state registration of real rights to immovable property and their restrictions: Law of Ukraine № 1952-IV of 01.07.2004 № 1952-IV. URL: [Electronic resource] - Access mode: [ukr.]

4. Spasibo-Fateeva I. V. Forms of ownership. /I. V. Spasibo-Fateeva // Bulletin of the Academy of Legal Sciences of Ukraine. № 3. 2009. № 3. P. 145--154. [ukr.]

5. Decision of the Berdyansk City District Court of the Zaporizhia Region in case № 2-1622 / 11 of November 3, 2014: Unified State Register of Court Decisions. URL: [Electronic resource] - Access mode: http://www.reyestr.court.gov.ua/Review/49239108 [ukr.]

6. Decision of the Prydniprovsky District Court of Cherkasy in the case № 711/3164/15ts (proceedings № 6/711/133/15) of 20.05.2015: Unified State Register of Court Decisions. URL: [Electronic resource] - Access mode: http://www.reyestr.court.gov.ua/Review/48235868 Access date 03.08.2020 [ukr.]

7. Decision in absentia of the Mukachevo City District Court of the Zakarpattia Region in case № 303/5985/19 (proceedings № 2/303/137/20) of 19 March 2020: Unified State Register of Court Decisions. URL: [Electronic resource] - Access mode: http://www.reyestr.court.gov.ua/ Review/88310995 Date of application 03.08.2020 [ukr.]

8. Decision of the Dzerzhinsky District Court of Kharkiv in case 638/15749/18 (proceedings № 23/638/142/19) of 14 January 2019. Unified State Register of Court Decisions. URL: [Electronic resource] - Access mode: http://www.reyestr.court.gov.ua/Review/49239108 [ukr.]

9. On electronic trust services: Law of Ukraine № 2155-VIII of 05.10.2017 № 2155-VIII. [Electronic resource] - Access modeURL: https://zakon.rada.gov.ua/laws/show/2155-19/ ed20200213\#Text [ukr.]

10. Bilotserkovets N. V. Technological neutrality and prohibition of discrimination as key principles of state regulation of electronic trust services: concepts and features. / N. V. Bilotserkovets // Entrepreneurship, economy and law. 2018. № 1. P. 103--109. [ukr.]

11. Maidanyk R. A. Problemy rehuliuvannia dovirchykh vidnosyn u tsyvilnomu pravo Ukrainy / R. A. Maidanyk: avtoref. dis. ... PhD of Law: 12.00.03. Kyiv, 2003. 31 p. [ukr.] 
12. Ioffe O. S. Civilistic doctrine of imperialism. / O. S. Ioffe / Selected works on civil law: From the history of civilist thought. Civil legal relationship. Critique of the theory of «economic law». Moscow., 2000. 448 p. [russ.]

13. Shishka R. B. Proprietary theory of intellectual property. / R. B. Shyshka // Bulletin of the Kharkiv National University of Internal Affairs. 2001. Vol. 16. P. 311--315. [ukr.]

14. Ryabchynska A. A. The right of trust security property in foreign countries: the experience of France and Romania. / A. A. Ryabchynska // Scientific notes of TNU. V. I. Vernadsky. Legal Sciences Series. 2019. Vol. 30 (69). № 3. 2019. P. 51--57. [ukr.]

15. Nekit K. G. Trust ownership as a way to ensure the fulfillment of obligations: an analysis of domestic and foreign legislation. / K. G. Nekit // Journal of Civilization. Vol. 21. 2016. P. 78--81. [ukr.]

16. Commentary on Part Two of the Civil Code of the Russian Federation for Entrepreneurs: Preparation. M. I. Braginsky and others; Moscow: Legal Culture, 1996. 546 p. [russ.]

17. Goncharuk A. A. The right of trust property. / A. A. Goncharuk // Bulletin of the Ministry of Justice of Ukraine. 2014. № 2. p. 97--101. [ukr.]

18. Mikheeva L. Y. Trust management of property. / L. Y. Mikheeva. // Commentary on legislation: monograph. Moscow: Lawyer. 2009. 238 p. [russ.]

\section{КІРІЯК О. Право довірчої власності: інтеграція зобов'язальних і пропрістарних елементів.}

У статті досліджується комплексний інститут цивільного права України «право довірчої власності», який поєднує в собі ознаки класичних речових і зобов'язальних правовідносин. У результаті проведеного аналізу виділено три основні науково-теоретичні підходи до визначення сутності права довірчої власності: облігаторний, респосесійний, комбінаторний.

Ключові слова: довірча власність, право довірчої власності, довірчі правовідносини, речові правовідносини, зобов’язально-правові відносини.

\section{КИРИЯК О. Право доверительной собственности: интеграция обязательственных и проприетарных элементов.}

В статье исследуется комплексный институт гражданского права Украины «право доверительной собственности», который имеет признаки классических вещных и обязательственных правоотношений. В результате произведенного анализа выделены три основных научно-теоретических подхода к определению сущности права доверительной собственности: облигаторный, респоссессионный, комбинаторный.

Ключевые слова: доверительная собственность, право доверительной собственности, доверительные правоотношения, вещные правоотношения, обязательственно-правовые отношения.

KIRIIAK O. The Trust Property Law: integration of obligatory and proprietary elements.

The article examines the complex institution of civil law of Ukraine «the right of trust», which combines the features of classical property and legal obligations. The study of trust property 
right should be considered as a new main highway direction in the whole science of civil law. At the same time, the lack of thorough research on the issues of empirical awareness and practical application of trust property law does not allow this article to cover all the problematic aspects of the implementation of this institution. In this regard, the author deliberately narrows the object of research to the analysis of various theoretical approaches to understanding the essence of trust property at the present stage, which, in our view, is crucial for the formation of the vector of further research in this area.

The implementation of a new comprehensive institution of trust property inevitably requires immediate editorial transformation of legislative acts, which is unjustified without thoughtful borrowing of foreign experience in legal regulation of the studied relations, including in its historical retrospect, careful analysis of all errors and «non-working» norms that have been made in recent years in the law of foreign countries.

As a result of the analysis, three main scientific and theoretical approaches to the definition of the essence of the right of trust were identified:

1. Obligatory approach (from the Latin obligatoria - obligations, security), whose representatives defend the view that a trust relationship, as binding, is characterized by the satisfaction of the interests of the authorized person by committing certain mandatory actions related party in respect of certain property belonging to the principal.

2. Respossessional approach (from the Latin res - thing, possessio - possession), whose representatives emphasize the purely material nature of trust, because, according to them, the powers of the trust owner, which is opposed by an indefinite number of persons constructed according to the scheme, which is similar to the powers of the owner and therefore can'tbe anything other than limited property rights.

3. Combinatorial approach (from the Latin combinant -- to combine, combine), whose representatives emphasize that the relationship of trust is currently at the junction of binding and material relations and therefore all the arguments of connoisseurs of previous trends here offer to use not as mutually exclusive or contradictory, but, conversely, complementary criteria.

Key words: trust property, the right of trust property, trust relationship, property relationship, legal relationship. 